\title{
MEDIA TUTORIAL KERAJINAN GERABAH DI LOMBOK BARAT BERBASIS MULTIMEDIA
}

\author{
Andi Yana Eka Nadi \\ Program Studi S1 Teknik Informatika \\ STMIK Bumigora Mataram \\ Email : Andiyanaekanadi@gmail.com
}

\begin{abstract}
ABSTRAK
Gerabah merupakan perkakas yang terbuat dari tanah liat yang dibentuk kemudian dibakar untuk dijadikan alat-alat yang berguna membantu kehidupan manusia, salah satunya adalah digunakan sebagai alat rumah tangga, namun seiring dengan perkembangannya, gerabah tidak hanya digunakan sebagai alat rumah tangga akan tetapi digunakan sebagai hiasan atau pernak pernik. Keahlian membuat gerabah ini hanya dimiliki oleh orang-orang tertentu yang sudah terbiasa dalam membuatnya, karena membuat gerabah memiliki tingkat kesulitan yang tinggi dan harus di pelajari dalam pembuatanya. Aplikasi media tutorial ini bertujuan menyampaikan informasi dan memperkenalkan gerabah khususnya bagi pengrajin pemula dan bisa menciptakan cara belajar baru yang mudah dipahami dan dimengerti oleh pengrajin gerabah khususnya bagi para pemula yang ingin belajar membuat kerajinan gerabah, sehingga kedepannya banyak pengrajin-pengrajin gerabah yang baru. Dalam pembuatan aplikasi Media Tutorial Kerajinan Gerabah ini penulis akan menggunakan Metode pengembangan multimedia Luther Sutopo. Adapun tahapannya adalah concept, Design, Material collecting, Assembly, Testing, Distribution. Hasil dari penelitian adalah sebuah aplikasi Media Tutorial Kerajinan Gerabah Berbasis Multimedia. Didalam aplikasi ini nantinya terdapat konten-konten informasi sejarah gerabah, jenis gerabah, alat dan bahan, dan proses pembuatan, gallery, dan about. Kesimpulan yang dapat diambil dari pembuatan aplikasi Media Tutorial Kerajinan Gerabah adalah dapat membantu masyarakat dan pengrajin pemula untuk belajar membuat kerajinan gerabah yang lebih menarik dan mudah dipahami dengan adanya aplikasi ini.
\end{abstract}

Kata kunci : Tutorial, Gerabah, Multimedia.

\section{PENDAHULUAN}

Gerabah merupakan perkakas yang terbuat dari tanah liat yang di bentuk kemudian di bakar untuk dijadikan alatalat yang berguna membantu kehidupan manusia, salah satunya adalah digunakan sebagai alat rumah tangga, namun seiring dengan perkembangannya, gerabah tidak hanya digunakan sebagai alat rumah tangga akan tetapi digunakan sebagai hiasan atau pernak pernik. Keterampilan dalam membuat gerabah telah dilakukan sejak zaman dahulu dan sudah menjadi perkembangan peradaban bangsa di nusantara, jejak sejarahnya pun jelas yaitu terwariskan hingga masa saat ini. Keahlian membuat gerabah ini hanya dimiliki oleh orang-orang tertentu yang sudah terbiasa dalam membuatnya, karena membuat gerabah memiliki tingkat kesulitan yang tinggi dan harus di pelajari dalam pembuatanya, salah satu cara untuk mempelajari teknikteknik pembuatan gerabah adalah dengan cara melihat langsung proses pembuatannya. Namun, berdasarkan survey dan wawancara yang penulis lakukan dengan ketua pasar seni di Banyumulek didapatkan data bahwa bagi para pemula yang ingin belajar membuat kerajinan gerabah dengan hanya melihat secara langsung yang hanya bisa dilihat dimana tempat pengrajin itu berada tanpa bisa dilihat atau dipelajari dimana-mana oleh pemula yang ingin belajar membuat gerabah, cara yang seperti ini akan sulit dimengerti, dimana kita ketahui sendiri bahwa membuat kerajinan gerabah memiliki tingkat kesulitan yang tinggi apalagi bagi para pemula tanpa adanya panduan yang bisa kita lihat setiap saat. 
Namun seiring dengan perkembangan ilmu pengetahuan dan teknologi informasi yang beragam dapat mempermudah kita memahami caracara dalam pembuatan gerabah, salah satunya adalah dengan menggunakan teknologi multimedia. Berbicara tentang multimedia adalah salah satunya tentang media pengajaran atau pembelajaran yang bisa memberikan sebuah tampilan yang lebih menarik dan lebih mudah di mengerti, sehingga bagi para pemula yang ingin belajar membuat kerajinan gerabah ini bisa menggunakan multimedia pembelajaran sebagai panduan dalam membuat kerajinan gerabah. Multimedia sangat banyak digunakan dalam kegiatan yang berhubungan dengan informasi dan pembelajaran yang dapat menyajikan sebuah informasi atau suatu cara pembelajaran yang menarik dan efisien serta lebih mudah di mengerti. Dengan multimedia juga kita dapat menggunakannya sebagai alat dan media untuk lebih memperjelas dan memperkenalkan cara membuat kerajinan gerabah yang lebih mudah untuk di mengerti. Seperti yang kita ketahui perkembangan multimedia interaktif sudah sangat pesat, multimedia sendiri merupakan penggabungan dari media antara teks, audio, gambar serta animasi yang dapat dibuat sebagai suatu aplikasi yang lebih menarik. Melihat potensi multimedia yang dapat dimanfaatkan sebagai media informasi dan pembelajaran yang menarik, maka penulis melakukan penelitian dengan tema "Media Tutorial Kerajinan Gerabah di Lombok Barat Berbasis Multimedia dengan Studi kasus di Banyumulek". Informasi yang ada nantinya akan diterapkan bagi semua orang, khususnya pengrajin pemula yang ingin belajar membuat kerajinan gerabah, dan merancangnya dalam bentuk sebuah aplikasi yang dapat digunakan sebagai panduan dalam belajar membuat kesenian gerabah yang lebih mudah dipahami, jika dibandingkan dengan hanya menggunakan lisan maupun tulisan.

\section{METODOLOGI}

\section{Metode Pengumpulan Data}

Pengumpulan data bertujuan untuk memperoleh data-data yang diperlukan untuk membuat sebuah aplikasi. Metode pengumpulan data yang dilakukan adalah dengan cara Study literature dan wawancara.

\section{Tahap Konsep (Concept) \\ Tujuan}

Tujuan dibuatnya ini, yakni untuk membantu memudahkan para pengrajin khusus pengrajin pemula untuk belajar membuat kerajinan gerabah dengan cara yang lebih efektif, interaktif dan efisien sehingga mudah dipelajari dimana-mana dan dipahami serta lebih menarik.

\section{Pengguna/Target User}

Sasaran pengguna aplikasi media tutorial ini terdiri :
a. Pengguna demografis:
1.Primer
2.Skunder
3.Jenis Kelamin
b. Psikografis

\section{Konten}

Konten yang akan dibuat dalam aplikasi ini adalah menampilkan informasi mengenai kerajinan gerabah yang ada di Banyumulek. Informasi yang ada meliputi: Proses pembuatan gerabah, bahan yang digunakan membuat gerabah, alat yang digunakan membuat gerabah, jenisjenis gerabah dan finishing.

\section{Konten Multimedia Yang Digunakan \\ - Gambar \\ Gambar yang digunakan untuk merancang aplikasi ini berasal dari karya penulis dan beberapa diambil dari internet.}

\section{- Suara}

Suara yang digunakan dalam aplikasi ini berformat *wav yang digunakan untuk kombinasi video. Digunakan untuk suara tombol, music pengiring, dan Intro. 


\section{- Animasi}

Animasi yang digunakan diolah dengan menggunakan software Adobe Flash CS6. Animasi disimpan dalam format *.swf. Digunakan untuk animasi seperti animasi tombol, animasi tulisan dan animasi gambar.

\section{- $\quad$ Video}

Video yang ada ini diambil langsung menggunakan kamera DSLR Nikkon D5200 dan Video ini diolah dengan menggunakan Adobe Premiere Pro CS3.

\section{Tahap Perancangan (Design)}

Dalam perancangan aplikasi yang akan dibuat ini, dimulai dari intro sebagai pembuka, kemudian masuk kedalam menu utama

\section{Struktur Navigasi}

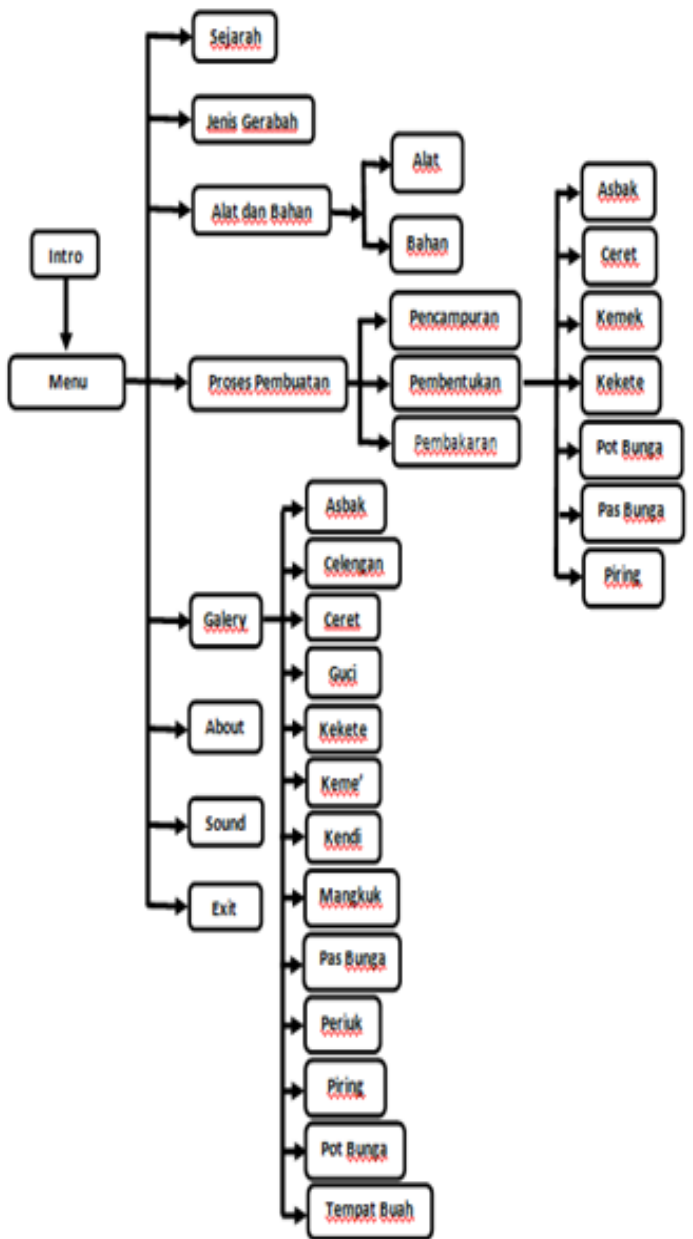

\section{Storyboard Aplikasi}

Storyboard adalah visualisasi ide dari aplikasi yang akan dibangun, sehingga dapat memberikan gambaran dari aplikasi yang akan dihasilkan

Tabel 3.3 Storyboard Aplikasi

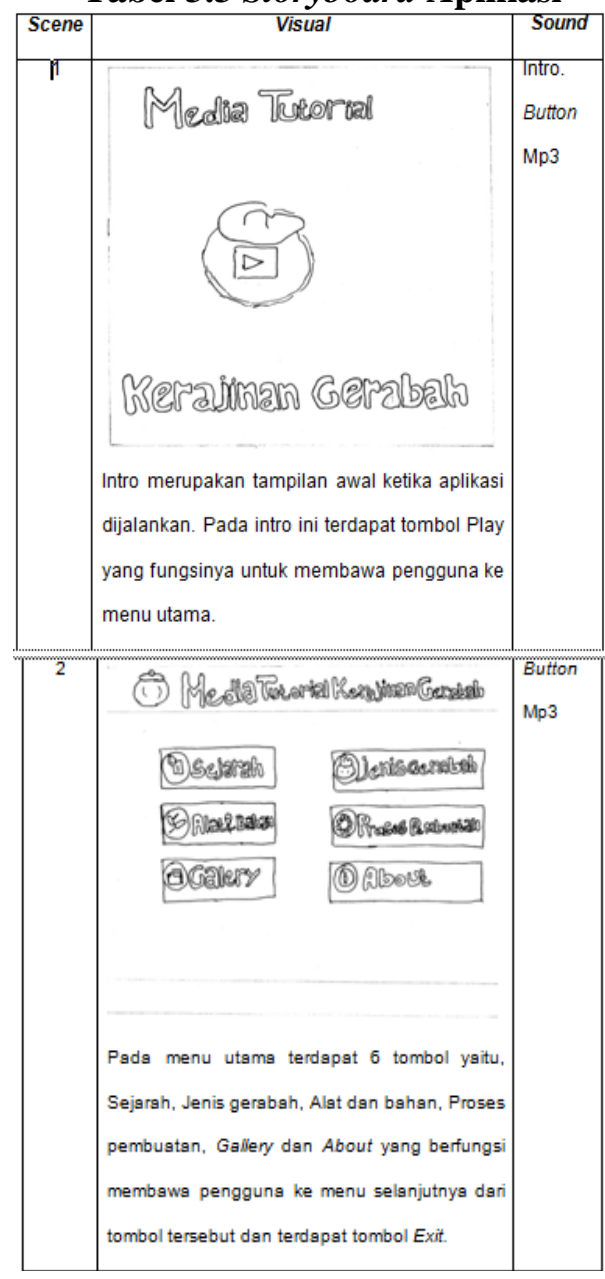

\section{Storyboard Video}

Tabel 3.4 Storyboard Video Proses Pencampuran

Gambar 3.1. Desain Navigasi Aplikasi 


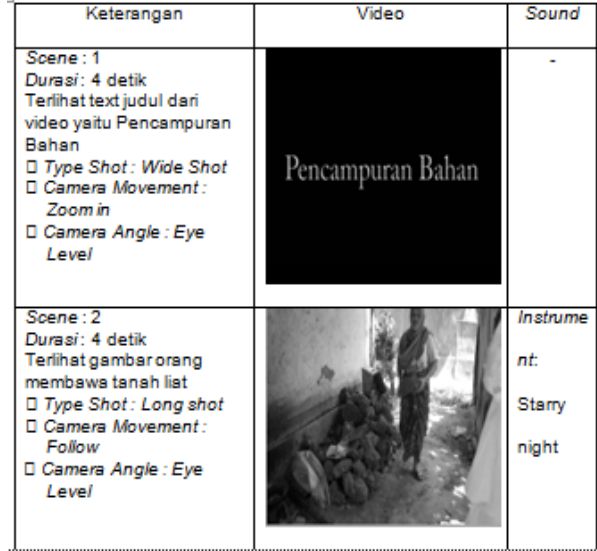

Tabel 3.5 Storyboard Video Pembuatan

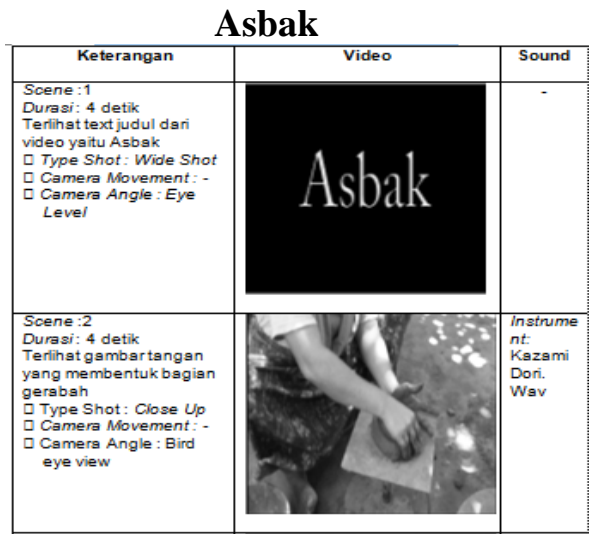

Tabel 3.6 Storyboard Video Pembuatan

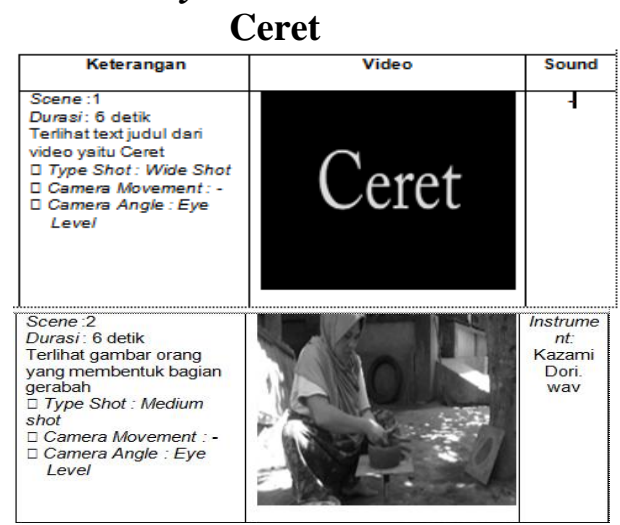

Tabel 3.7 Storyboard Video Pembuatan

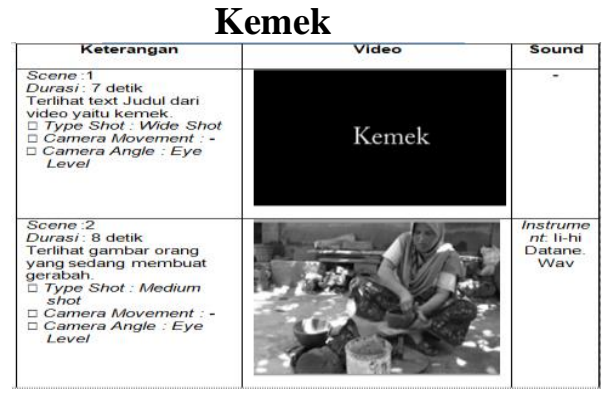

Tabel 3.8 Storyboard Video Pembuatan Kekete

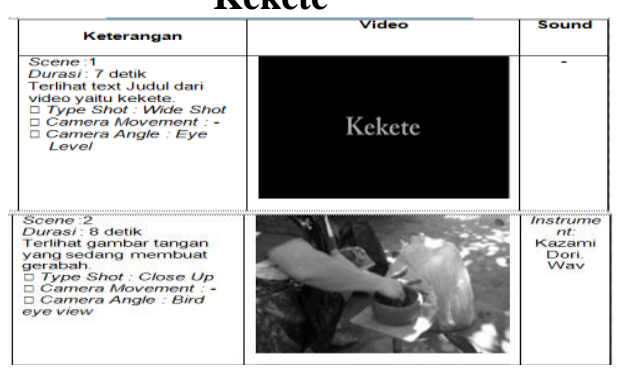

Tabel 3.9 Storyboard Video Pembuatan Pot

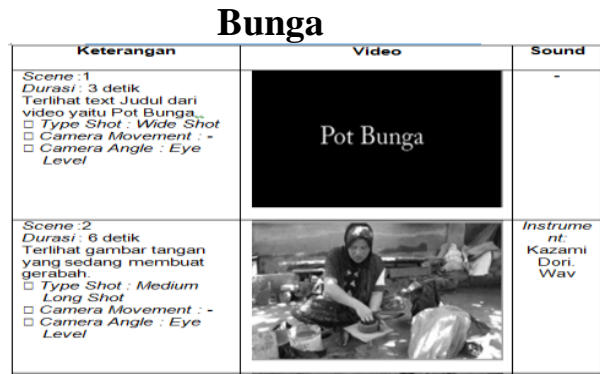

Tabel 3.10 Storyboard Video Pembuatan Vas Bunga

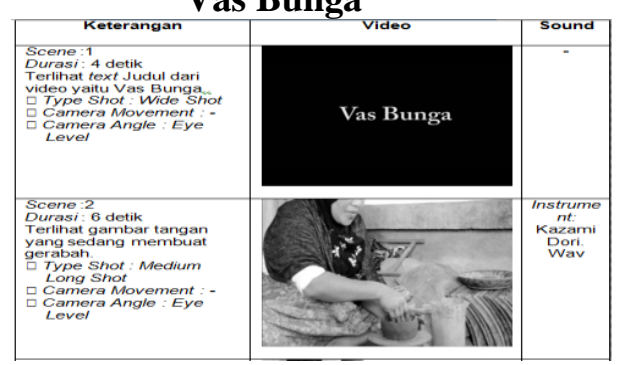

Tabel 3.11 Storyboard Video Pembuatan

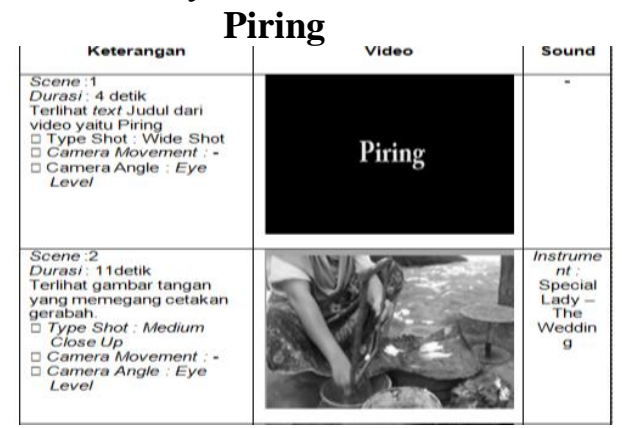

Tabel 3.12 Storyboard Video Proses

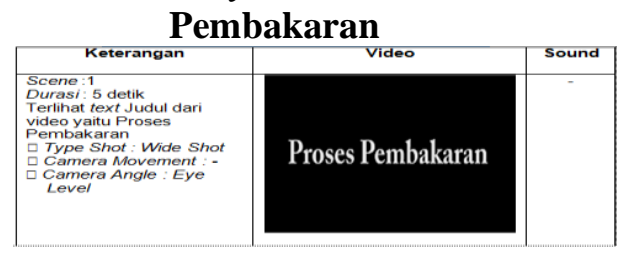




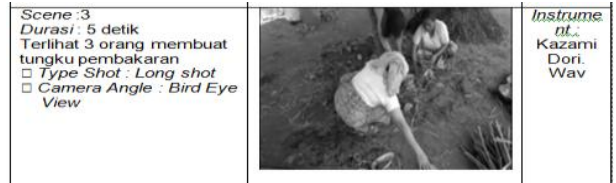

III. HASIL DAN PEMBAHASAN

\section{Authoring Menggunakan Adobe Flash CS6}

\section{a. Halaman Intro}

Pada aplikasi ini intro,yaitu intro yang berisi animasi teks, dan animasi gambar.

Intro

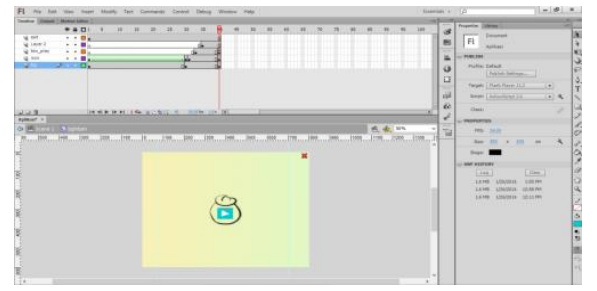

Gambar 4.5 Tampilan Project Intro

b. Halaman Menu Utama

Pada halaman menu utama aplikasi terdapat teks "Media Tutorial Kerajinan Gerabah". Terdapat 7 buah tombol yaitu tombol menu.

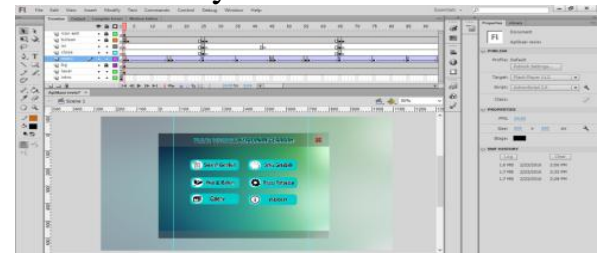

\section{Gambar 4.6 Tampilan Project} Menu Utama

c. Halaman Menu Sejarah

Halaman menu sejarah merupakan halaman materi yang menampilkan teks yang menjelaskan tentang sejarah gerabah.

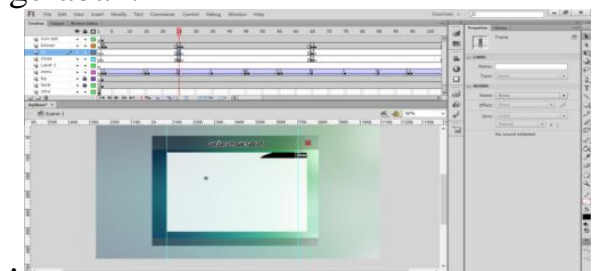

Gambar 4.7 Tampilan Project Menu Sejarah

d. Halaman Menu Jenis Gerabah

Halaman menu utama jenis gerabah merupakan halaman informasi tentang jenis gerabah. Dalam membuat halaman menu jenis gerabah dibutuhkan bahan-bahan seperti gambar, dan teks.

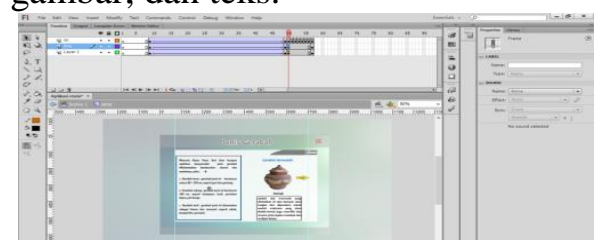

Gambar 4.8 Tampilan Project Menu Jenis Gerabah

e. Halaman Menu Alat dan Bahan

Halaman menu alat dan bahan merupakan halaman yann berisi informasi tentang alat dan bahan yang digunakan membuat gerabah.

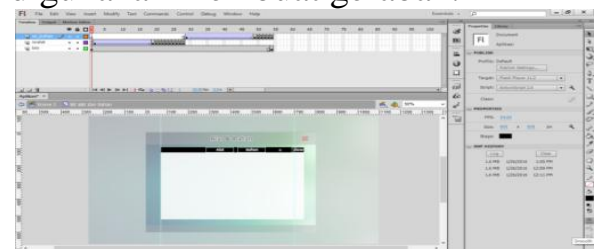

Gambar 4.9 Tampilan Project Menu Alat dan Bahan

f. Halaman Menu Proses Pembuatan

Halaman menu proses pembuatan terdapat 3 tombol yaitu pencampuran, pembuatan, pembakaran. Masingmasing tombol berisi tentang tahap pembuatan gerabah yang berbentuk video

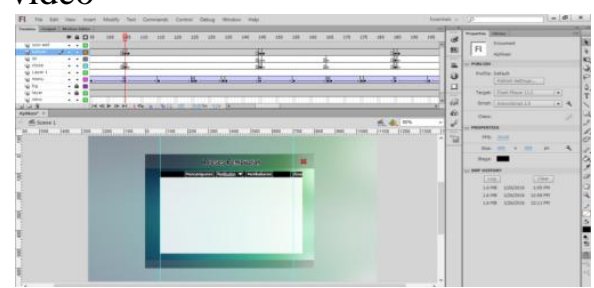

Gambar 4.10 Tampilan Project Menu Proses Pembuatan

g. Halaman Menu Gallery

Halaman menu gallery merupakan halaman yang berisi gambar dan teks mengenai informasi gambar tersebut.

1) Halaman Utama Gallery

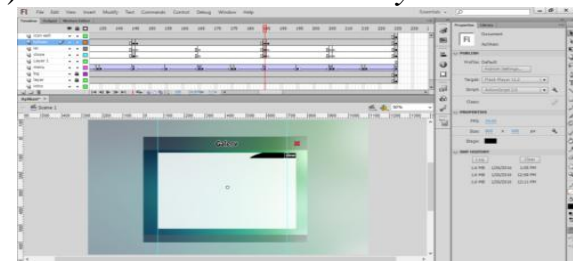

Gambar 4.11 Tampilan Utama Project Menu Gallery

2). Halaman Isi Gallery 


\section{h. Halaman Menu About}

Halaman menu about berisi tentang identitas penulis dan tentang aplikasi ini.

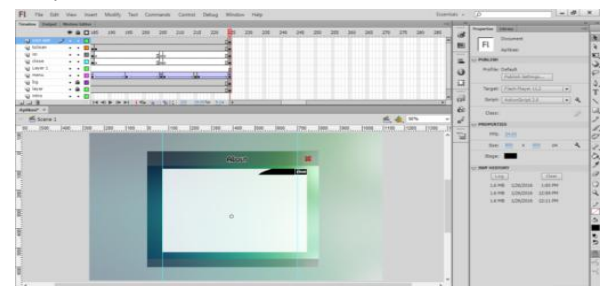

\section{Gambar 4.13 Tampilan Project Menu About}

\subsection{Pembahasan}

\subsubsection{Uji Coba (Testing)}

Uji coba atau testing dilakukan untuk mengetahui apakah program yang sudah dibangun, dapat bermanfaat dan diterima oleh pengguna.

\subsubsection{Alpha Test}

Alpha test dilakukan langsung oleh pembuat program untuk menguji apakah program yang telah dbuat berjalan dengan benar. Berikut tabel pengujian aplikasi:

\section{Tabel 4.4 Alpha Test}

\begin{tabular}{|c|c|c|c|c|}
\hline \multirow{2}{*}{ No } & \multirow{2}{*}{ Halaman } & \multicolumn{2}{|c|}{ Berfungsi } & \multirow{2}{*}{ Keterangan } \\
\hline & & $\mathrm{Ya}$ & Tidak & \\
\hline \multirow{4}{*}{1} & \multicolumn{4}{|l|}{ Intro } \\
\hline & a. Animasi Intro & $\checkmark$ & & $\begin{array}{l}\text { Animasi teks menjadi } \\
\text { icon gerabah }\end{array}$ \\
\hline & b. Tombol play & $\checkmark$ & & $\begin{array}{l}\text { Masuk ke halaman } \\
\text { menu utama }\end{array}$ \\
\hline & c. Sound & $\sqrt{ }$ & & Sound button \\
\hline \multirow{6}{*}{2} & \multicolumn{4}{|l|}{ Menu utama } \\
\hline & a. Tombol Exit & $\sqrt{ }$ & & Keluar dari aplikassi \\
\hline & b. Tombol sejarah & $\sqrt{ }$ & & $\begin{array}{l}\text { Menuju ke halaman } \\
\text { sejarah }\end{array}$ \\
\hline & $\begin{array}{l}\text { c. Tombol ienis } \\
\text { gerabahh }\end{array}$ & $\sqrt{ }$ & & $\begin{array}{l}\text { Menuju ke halaman } \\
\text { jenis gerabah }\end{array}$ \\
\hline & $\begin{array}{l}\text { d. Tombol alat dan } \\
\text { bahan }\end{array}$ & $\sqrt{ }$ & & $\begin{array}{l}\text { Menuju ke halaman } \\
\text { menu alat dan bahan }\end{array}$ \\
\hline & $\begin{array}{l}\text { e. Tombol proses } \\
\text { pembuatan }\end{array}$ & $\sqrt{ }$ & & $\begin{array}{ll}\text { Menuju ke halaman } \\
\text { menu } & \text { proses } \\
\text { pembuatan } & \end{array}$ \\
\hline
\end{tabular}

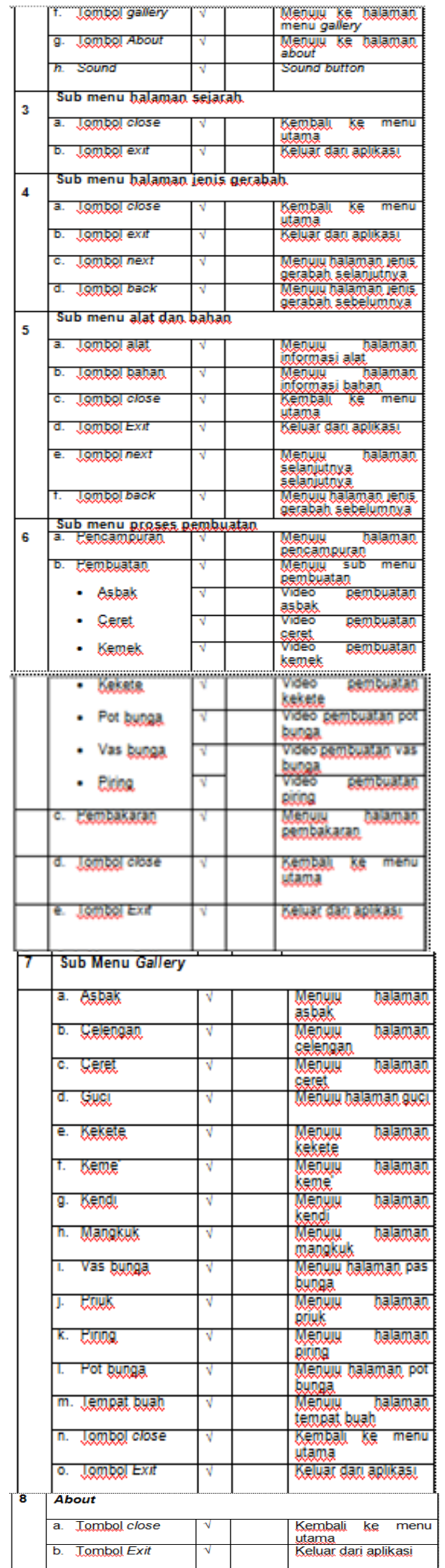

\subsubsection{Betha Test}

Betha test dilakukan dengan metode angket untuk pengrajin gerabah di Banyumulek dengan cara mendemokan 
aplikasi dan memberi kuisioner kepada pengrajin

Berikut ini hasil metode angket yang diberikan kepada pengrajin:

Tabel 4.5 Hasil Uji Coba Angket Pengrajin

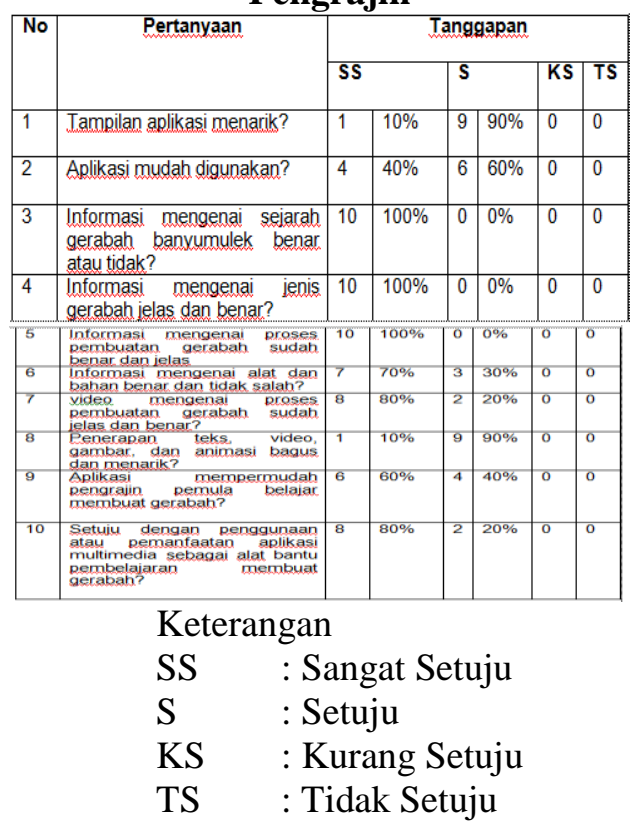

Berdasarkan hasil angket diatas dinyatakan bahwa semua pertanyaan yang diajukan untuk pengrajin diperoleh tanggapan setuju dengan kemudahan dalam menggunakan aplikasi dan konten informasi pada aplikasi sudah jelas dan benar. Selain itu juga pengrajin setuju dengan tampilan aplikasi media tutorial kerajinan gerabah ini, dengan adanya aplikasi media tutorial ini bisa mempermudah pengrajin dan pemanfaatan sebagai alat bantu dalam belajar membuat gerabah untuk pengrajin pemula

\section{SIMPULAN DAN SARAN}

\section{Kesimpulan}

Berdasarkan rumusan masalah pada Bab I dapat diambil kesimpulan sebagai berikut:

1. Telah dibangun alat bantu berupa aplikasi Media Tutorial Kerajinan Gerabah Berbasis Multimedia dengan menggunakan Adobe Flash CS6 yang mampu menampilkan teks, gambar, animasi, video dan sound yang memudahkan pengrajin pemula dalam belajar membuat kerajinan gerabah.

2. Berdasarkan hasil uji coba atau testing aplikasi yang dilakukan dengan metode betha test pada $\mathrm{Bab}$ IV, seluruh responden ataupun pengrajin pemula di desa Banyumulek setuju dengan aplikasi dan konten informasi pada aplikasi sudah jelas dan benar, serta pengrajin setuju dengan tampilan aplikasi, sehingga media tutorial kerajinan gerabah ini bisa membantu mempermudah pengrajin pemula belajar dimana saja untuk membuat kerajinan gerabah.

\section{Saran}

Dari paparan pada bab-bab sebelumnya, maka penulis sadar bahwa penelitian ini masih sangat jauh dari sempurna, sehingga penulis mengemukakan saran sebagai berikut :

1. Penulis sadar bahwa kualitas apilkasi ini masih jauh dari sempurna sehingga kedepannya perlu diperbaiki.

2. Penulis merasa kualitas audio dan video masih kurang sehingga perlu diperbaiki.

3. Materi yang disampaikan dalam aplikasi masih kurang sehingga perlu ditambah dan dilengkapi.

Demikian kesimpulan dan saran dari penulisan penelitian ini, dengan harapan dapat bermanfaat bagi semua pihak, saran yang bersifat membangun sangat diharapkan untuk dapat menyempurnakan penelitian ini.

\section{REFERENSI}

Bawantara, Agung. (2008). PanduanMembuat Video Keluarga.Jakarta :Kawan Pustaka.

Binanto, Iwan. (2010). Multimedia Digital-DasarTeori Dan Pengembangannya.

Yogyakarta : CV. Andi Offset.

Hajar A.K, M. (nd), internet.Home / Pemula / Tutorial / Mengenal Macam-Macam Sudut Pandang (Angle) Dalam Fotografi. Di akses pada alamat 
http://www.kelasfotografi.com/2015/0

2/mengenal-macam-macam-sudut-

pandang.html, di akses pada tanggal 25-05-2015 jam 10.45

padatanggal 19-02-2015 jam 16:35 Wita.

Irvana, Sindy.(2011) bahan pembuatan gerabah. Di akses pada alamat http://sindyirvana.blogspot.co.id/2011/ 12/b-bahan-pembuatan.html, tanggal 19-02-2015 jam 16:23 wita

Izham, Dedy. Cara Cepat Belajar Adobe Flash. Diunduh pada alama thttp://ilmukomputer.org/wpcontent/uploads/2012/11/BAB_1_Pe ngenalan-Adobe-Flash.pdf, diakses pada tanggal 06-08-2015 jam 19.20 WITA.

Riyana, Cepi. Digital Video Editing with Adobe Premiere Pro.Diunduhpadaalamat http://file.upi.edu/Direktori/FIP/JUR. KURIKULUM DAN TEK. PEND IDIKAN/197512302001121-

Saeful.(2012). Sejarah gerabah.Diunduh padaal alamat http://saefulhistorysejarah-saeful

history.blogspot.co.id/2012/02/geraba h.html.Di akses pada tanggal 19-022015 jam 16:47 Wita.

photoshop.html, diakses tanggal 19-02-2015 jam 14.00 WITA.

Vaughan, Tay. (2004).multimedia.making it work.Yogyakarta: Andi offset.

Wikipedia.Tembikar. Diunduh pada alamat https://id.wikipedia.org/wiki/Tembikar , diakses pada tanggal 19-02-2015 jam 16:21 Wita.

Zaenudin, Akbar (2012) Geliat gerabah lombok. Diakses pada alamat http://sGeliat IndustriGerabah di BanyumulekLombok.html tanggal 2101-2015 Jam 16:30 wita 